Entrevista com Ulpiano Toledo Bezerra de Meneses

Interview with Ulpiano Toledo Bezerra de Meneses

Ulpiano Toledo Bezerra de Meneses é um dos maiores nomes, no país, no campo dos estudos sobre cultura material, cultura visual e museus. Doutor em Arqueologia Clássica pela Sorbonne, é titular aposentado de História Antiga e docente do Programa de Pós-Graduação em História Social da Faculdade de Filosofia e Ciências Humanas da Universidade de São Paulo, da qual recebeu o título de professor emérito em 2008. Foi também agraciado com a comenda da Ordem Nacional do Mérito Científico, em 2002.

Além de uma longa trajetória acadêmica, na qual publicou mais de uma centena de capítulos de livros e artigos, e organizou várias coletâneas, o professor Ulpiano tem também uma vasta experiência no campo institucional. Dirigiu o Museu de Arqueologia e Etnologia e o Museu Paulista, ambos ligados à USP, e integrou conselhos de órgãos públicos atuantes no campo do patrimônio, como o Conselho de Defesa do Patrimônio Histórico, Arqueológico, Artístico e Turístico (CONDEPHAAT), da Secretaria Estadual de Cultura de São Paulo, e o Conselho do Instituto do Patrimônio Histórico e Artístico Nacional (IPHAN), no qual ainda atua. É fellow do Royal Anthropological Institute of Great Britain and Ireland, e participou dos comitês brasileiros do ICOM (International Council of Museums/UNESCO) e do ICOMOS (International Council of Monuments and Sites/UNESCO).

Essa entrevista foi realizada em 31 de março de 2011, dia em que o professor Ulpiano veio ao CPDOC proferir a aula inaugural do Programa de Pós-Graduação em História, Política e Bens Culturais, em torno do tema "A problemática do valor no campo do patrimônio cultural". A entrevista teve como objetivo percorrer sua longa trajetória, e explorar alguns temas que marcaram a sua reflexão, tais como o ensino da história, a visualidade, os museus e seu papel na apreensão da historicidade. 


\section{Entrevista com Ulpiano Toledo Bezerra de Meneses}

Interview with Ulpiano Toledo Bezerra de Meneses

Concedida a Luciana Quillet Heymann e Aline Lopes de Lacerda Rio de Janeiro, 31 de março de 2011

O primeiro dado biográfico que nós temos é o da sua graduação em letras clássicas na USP, onde você ingressou em 1955. Mas gostaríamos de começar antes disso, falando um pouco sobre sua infância. Onde você nasceu?

- Nasci em um belo dia de sol, na cidade de Cunha, que fica no limite entre São Paulo e Rio. Tenho algum componente fluminense na minha personalidade, porque Cunha fica na beira, justamente, da serra do Mar, que desce depois para Paraty. Mas não morei em Cunha. Como meu pai era juiz, ele circulou pelo interior todo, até chegar à capital, São Paulo. Então, foi lá que eu fiz o essencial

Luciana Quillet Heymann é pesquisadora do CPDOC/FGV e professora da Escola Superior de Ciências Sociais da FGV e do Programa de Pós-Graduação em História, Política e Bens Culturais do CPDOC, Rio de Janeiro, Brasil (luciana.heymann@fgv.br).

Aline Lopes de Lacerda é professora do Departamento de Ciência da Informação da Universidade Federal Fluminense, Niterói, Brasil (alopeslacerda@gmail.com).

Est. Hist., Rio de Faneiro, vol. 24, no 48, p. 405-431, julho-dezembro de 2011. 
dos meus estudos. Completei o primário em uma escola historicamente muito relevante sob vários aspectos, inclusive do patrimônio cultural, que era a chamada Escola da Praça, na praça da República. Foi o primeiro edifício, na República Velha ainda, construído especificamente para ser uma escola. Depois passei por escolas como a Escola dos Maristas e o São Bento. O São Bento era uma escola meio sombria, aquele gosto alemão pela tranquilidade e a meditação. Depois é que fui perceber que tinha aproveitado muito disso. Agora, as coisas mais decisivas começaram mesmo nas vésperas do vestibular.

\section{No momento de escolher a carreira? Como foi a opção por letras?}

- Como meu pai era magistrado, nunca imaginei ser nada na vida além de magistrado. Advogado não. Eu ia fazer direito, mas pensando que trabalharia depois na magistratura, como ele. $E$ também não poderia escapar da vocação familiar e do nome: Ulpiano vem do latim vulpes, que significa raposa. Então, Ulpianus é aquele que tem as qualidades da raposa. As boas, entenda-se. É o nome de um jurista do século II da nossa era e um jurista dos mais importantes. O mais importante se chamava Papiniano. Meu pai queria me chamar de Papiniano, e minha mãe é que disse: "Não. O apelido dele depois vai ficar humilhante". Então, havia essa tradição, que para mim era tranquila e, realmente, eu via sentido naquilo. Claro que me interessava muito por literatura, lia bastante. Mas ia fazer direito, e meu pai é que me sugeriu: "Você não quer fazer letras? Porque a primeira interpretação do direito é literal”. Era uma visão formal do direito que era corrente naquela época e que me pareceu adequada. Tudo bem. Prestei também letras. E aí começou uma inversão de interesses. Matriculei-me na Faculdade de Direito, e completei três anos de estudos. Mas já no terceiro ano, eu me sentava no fundo - era a Faculdade do Largo de São Francisco, com aquelas salas imensas, hieráticas -, sentava lá no fundo, e li toda a tragédia grega na última fileira.

\section{Como foi a experiência de cursar letras na USP, naquele momento?}

- O curso de letras clássicas foi extraordinariamente importante do ponto de vista instrumental. Não tive nenhum professor que orientasse minha cabeça, mas que me instrumentasse, sim. Tive gente muito competente e muito séria, mas não tive, por exemplo, alguém como o Antonio Candido, que estava na seção vizinha - depois departamento -, para abrir horizontes. Eu aproveitei muito do Antonio Candido em cursos de literatura que ele dava no Centro Dom Vital. Eu tinha contato com esse pessoal lateralmente, não no departamento. Insisto que alguns professores deixaram em mim um lastro que, absolutamente, não posso negar. Além disso, o curso foi uma base fundamental para perceber uma dimensão linguística da vida. E aí surgiu ainda outra abertura, que foi a existência de um professor de grego, um francês que trabalhava com tradição literária grega, 
um erudito extraordinário. Era uma pessoa muito séria, mas muito agradável e desejosa de beneficiar os outros, e de deixar aqui descendentes, quando voltasse para a França. Aprendi grego e latim, e quando esse professor pensou efetivamente em voltar, ele escolheu alguns alunos para enviar à França como bolsistas, para fazer história da filosofia grega, estudos bizantinos, grego moderno, latim e assim por diante. Foram uns cinco ou seis. Ele me disse: "Você gosta dessas coisas de civilização, não é? Você não quer fazer arqueologia?”. Eu respondi na hora que sim. Eu estava querendo era ir para a França, mas também porque o que se chamava então de história da civilização - era uma categoria altamente francesa - era o estudo dessas sociedades antigas. Então, eu me licenciei em letras clássicas no final de 1959 e fui para a França. No primeiro ano, estudei no Instituto de Arte e Arqueologia, que faz parte da Faculdade de Letras e Ciências Humanas, a Sorbonne.

\section{Qual era o nome desse professor francês?}

- Era Robert [Henri] Aubreton. Era uma pessoa humana deliciosa. A gente se entendeu muito bem com a família dele, seja aqui, seja depois, na França.

Além dele, houve outras figuras marcantes? Havia outros franceses? Havia ainda a marca da missão francesa na USP, nesse momento?

- Não. Ou melhor, havia em outras áreas, mas não em letras clássicas. Por exemplo, o pessoal da filosofia, e mesmo de história, sociologia. Não os da primeira fase, os heróis anteriores, como Braudel. Havia inclusive, eu diria, uma espécie de genealogia muito vivida e, às vezes, até mesmo utilizada para autodivulgação. Mas em letras não. Em letras havia, sim, professores de origem portuguesa. O Fidelino de Figueiredo tinha acabado de se aposentar, e eu fui aluno do genro e sucessor dele, o Antonio Augusto Soares Amora, de quem fui monitor por dois anos. Em literatura portuguesa, por exemplo, tive uma experiência metodológica de como se estuda a literatura, que foi muito importante. Tive professores extremamente competentes e eruditos, que me deram informação e uma certa disciplina, mas não é que eles me tenham aberto a visão de mundo. E nem mesmo na França tive essa abertura. Acho que isso se deu mais por contatos pessoais que começaram lá... Mas isso é um segundo capítulo.

Antes de passar a outro capitulo, gostaria de saber o que o levou a aceitar prontamente a sugestão de fazer arqueologia. Foi a influência desse professor? O que era fazer arqueologia naquele momento?

- Certamente, eu poderia racionalizar a minha escolha e dizer: foi por tal e tal razão. Mas aí seria uma história teleológica, para explicar como é que eu che- 
guei até aqui. Não foi nada disso. Acho que foi uma intuição. Em primeiro lugar, no curso de letras clássicas havia uma disciplina esquisitíssima que se chamava história greco-romana. Mas não era a história, por exemplo, da expansão da koiné até Roma ou, a partir de certo momento, da expansão política e econômica de Roma. Um pedaço era história da Grécia e outro pedaço era história de Roma. A história da Grécia parece que terminava no século II a.C. e depois começava outro negócio diferente, era outra caixa de sapato. Mas, de qualquer maneira, essa disciplina despertou um interesse pela história da Grécia. Quando se falou em arqueologia, eu disse: "Acho que eu embarco nessa”. Mas não que eu tivesse um horizonte bem definido do que iria fazer e do que significaria isso depois como carreira, como interesse intelectual ou como campo de pesquisa.

Então, em 1959, você zarpa para Paris com uma bolsa de estudos para fazer arqueologia.

- Para fazer arqueologia clássica. Mas acontece que no Instituto de Arte e Arqueologia, ao contrário de toda a tradição americana, o que havia era história da arte, essencialmente. Tanto assim que o instituto chamava-se Instituto de Arte, e a arqueologia era um complemento. No fundo, não se tratava propriamente de arqueologia, mas daquelas obras de arte que a arqueologia havia colocado à disposição do especialista. Então, eu diria que meu contato inicial com esse universo material foi por via da história da arte. Durante o primeiro ano, fiz vários cursos - história da arte romana, história da arte grega etc. Não havia nenhuma preocupação nem teórica nem metodológica com a produção do conhecimento nessas áreas. Era a coisa já dada como um a priori. Depois do primeiro ano, acharam que eu tinha condições de ser admitido à Escola Francesa de Atenas.

\section{O que era essa Escola Francesa de Atenas?}

- Não era propriamente uma escola. Chama-se assim porque era a tradição do século XIX. Ela é de 1856 ou qualquer coisa assim. ${ }^{1}$ Foi a primeira missão arqueológica estrangeira que se instalou na Grécia. É uma escola antiquíssima, de uma tradição muito venerável e que tinha estabelecido um sistema que eles chamavam de promoção, de quatro membros franceses por ano, que ficavam três anos na Grécia. E começaram a aceitar também colaboradores estrangeiros, principalmente belgas e suíços, quase sempre um por ano. Acharam que eu podia ser aceito como membro estrangeiro, e então comecei a fazer uma série de cursos que eram dados para os candidatos que se preparavam para a Escola Francesa.

Que tipo de cursos?

- Por exemplo, na Escola Prática de Altos Estudos, fiz epigrafia, história das religiões etc. No Departamento de Antiguidades Gregas e Romanas do Mu- 
seu do Louvre, que era gerido, exatamente, por antigos membros da Escola Francesa, tive aulas com dois grandes mestres: Pierre Devambez, especialista em cerâmica grega, e Jean Charbonneaux, em escultura grega. Era um grupinho de seis ou sete pessoas, que se reunia às quatro horas, quando o museu fechava. Era uma delícia, porque o museu ficava todo à nossa disposição; as vitrinas eram abertas. A gente se sentia à vontade $\mathrm{e}$, realmente, aprendi muito. Foi meu primeiro contato com a coisa física, as fontes materiais...

Enquanto você está fazendo o curso de arqueologia, você também está fazendo esses cursos?

- Não. Aí interrompi arqueologia e me inscrevi no doutorado, à época se chamava doutorado de terceiro ciclo. Meu orientador em Paris também era antigo membro da escola. O resultado do meu trabalho na Grécia, se eu participasse das escavações, seria usado para a minha tese. Já no primeiro ano fui escalado para duas escavações, que foram as minhas duas experiências principais na Grécia.

Como foram essas experiências? Onde eram os sítios?

- Uma foi em Argos, que hoje não é grande coisa, mas se a gente pensar na Ilíada, toda a Argólida era um grande foco de poder na Grécia. Era a escavação de uma estrada romana. Mas a grande experiência, que começou inclusive nesse mesmo ano, foi na ilha de Delos, onde me fixei. Delos é interessante porque é um santuário desde a época arcaica... A ocupação de Delos começa a ser significativa, inclusive para a Grécia contemporânea, no século VI. Depois surge uma cidade. Quando Roma avança para o Mediterrâneo oriental, no século II a.C., há uma série de circunstâncias que faz com que Delos se transforme no primeiro porto do Mediterrâneo. Aliás, o primeiro entreposto entre o Oriente e a Itália. Foi uma cidade que cresceu em 50 anos, transformando-se em metrópole. Depois descobri que isso ia favorecer o entendimento de uma série de questões naquela que passou a ser a minha área de especialidade, pintura grega, especialmente pintura mural. Porque a escavação que estava sendo feita já não era mais no santuário; era em área de habitação. Era um interesse meu, ainda não definido, ligado ao urbanismo e à habitação, e dentro da habitação, ao problema da qualificação do espaço com pintura mural. Foi uma descoberta... Participei dessas escavações por dois anos, nos quais foi possível trazer à luz, estudar e, mais tarde, publicar um quarteirão inteiro. Trabalhei com a pintura mural desse quarteirão. $\mathrm{E}$ foi com isso que fiz minha tese, quando voltei para a França. Além disso, trabalhando na reserva do museu, encontrei cerca de 40 ou 50 caixotes com fragmentos de estuque pintados. 
Que museu é esse? Havia um museu em Delos?

- Sim, um museu local. Porque Delos, na época das escavações - ainda hoje é um pouco isso - era uma ilha sem habitantes, com pouca vegetação, quase tudo rochedo. Agreste, mas linda! Toda a ilha é um sítio arqueológico. Então, era necessário que houvesse um museu, inclusive para que as autoridades gregas tivessem um posto de fiscalização permanente, e para que você levasse para lá as peças encontradas, aquilo que virava peça de museu. Descobri então, na reserva do museu, esses caixotes, que estavam lá desde a famosa escavação de 1914, que envolveu cerca de 300 operários. Hoje já não se faz mais isso, mas à época havia fundos e um mecenas, o duque de Loubat. Foi então, pela primeira vez, que se desencavou a cidade helenística, o teatro, a ágora e assim por diante. Só que os escavadores não se interessavam por fragmentos de estuque. Eles se interessavam por escultura, por arquitetura e por epigrafia. O resto foi deixado de lado, e eu fui o sucessor.

\section{Qual a importância desses fragmentos?}

-O que interessava nessa pintura era justamente o fato de ser uma pintura corrente, papel pintado. Esse caráter ordinário me deu uma série de pistas para entender o que ela poderia significar na organização do habitar, sobretudo, depois que descobri que os quadrinhos decorados que apareciam nesses fragmentos reproduziam, no século II a.C., aquilo que os próprios gregos consideravam a grande pintura, que era a do século IV a.C. O que significa isso? Que ninguém queria jogar no escuro com a pintura contemporânea, queriam copiar a pintura que já estava consagrada, que a gente conhece agora por intermédio das tumbas dinásticas da Macedônia.

\section{Mas qual seria a pintura contemporânea ao século II a. C.?}

- Em Delos, outro tipo de pintura, que se encontrava fora das casas, principalmente nas encruzilhadas. Ela traz uma série de marcas do que seria a pintura de então, como a construção das figuras com toques de cor, e não com linhas, a perspectiva e uma série de outros aspectos. Era uma pintura litúrgica e etnicamente marcada, sobretudo porque os cultos e as figuras a que se refere estão associados a um contexto religioso, de escravos romanos. A outra não é etnicamente marcada. E a gente sabe que quando Delos virou um importante entreposto, por lá circulavam sírios, fenícios, egípcios, italianos, romanos etc. Mas nenhum traço étnico marcava a pintura nas casas. Era tudo a mesma coisa. Aí você entende uma porção de coisas. O que amalgamava esse pessoal todo que ia para Delos era o comércio, que funcionava como uma linguagem comum. A única linguagem? Não. Era necessário legitimar e valorizar essa atividade comercial, o que você fazia mobilizando as casas, adornando as habitações. 
Baseando-se em um modelo grego anterior, certo?

- Um modelo que tinha que ser grego porque não podia ser nem fenício, nem romano, nem egípcio, porque tinha que mostrar uma convergência de interesses. Então, você entende o que significa uma sociedade de altíssima mobilidade social, mas toda amarrada no comércio marítimo. Desenvolvi esse tema na tese de doutorado. Foi minha primeira oportunidade de ver que a história da arte podia ajudar a entender outros aspectos que não a estética das coisas. Mas foi por conta própria. Eu diria que a única influência que tive a esse respeito, nesse momento, foi de uma figura extraordinária que marcou toda a minha geração na Europa, que se chamava Ranuccio Bianchi-Bandinelli.

\section{Quem foi essa figura?}

- Em primeiro lugar, era um nobre; em segundo lugar, era um comunista, o que, aliás, na Itália, no momento, não causava grande estranheza. Foi uma figura que, a meu ver, renovou a história da arte, pelo menos a história da arte antiga, na academia. Eu me sentia muito mais membro da geração que ele formou na Itália, com quem mantive muito contato depois, do que com a própria geração francesa, com a qual mantive mais relações de amizade.

\section{E onde você teve contato com ele?}

- Em Roma. Isso porque eu estava trabalhando com pintura e ele também havia trabalhado com pintura, principalmente pintura pré-romana, mas da Itália, em cidades como Nápoles, Pompeia, Herculano e assim por diante. A primeira grande enciclopédia moderna - quer dizer, do século XX, porque no século XIX houve outras - sobre a Antiguidade grega e romana, principalmente no campo da arte, foi ele que organizou. Foi a primeira vez que eu vi alguma coisa que se chama história social da arte. Hoje, acho meio estranho falar em história social da arte ... Sei o que é história artística do social, mas tenho uma certa dificuldade de entender história social da arte. Mas foi a primeira vez que vi alguma coisa nessa perspectiva. Quer dizer, quando falei de abrir horizontes, estava me referindo a esse tipo de coisas. Foi a primeira vez que me aproximei da tal cultura material com outra perspectiva.

Nós estávamos falando há pouco sobre a conexão daquelas manifestações artísticas com todo um contexto social. Você não chamaria isso de história social da arte?

- Não. A minha resposta é anacrônica porque estou respondendo na perspectiva de hoje, certo? Não que eu tenha procurado fazer a tal história artística do social em vez da história social da arte. Isso é o que eu penso hoje. Fazer história social da arte não é fazer história da sociedade; é fazer história da arte, portanto, de um segmento da sociedade extremamente importante para que a socie- 
dade exista como tal, mas que você isola. Só que você coloca uma espécie de ponte e vai então estabelecer as relações entre arte e sociedade. Essa é uma visão legítima da história da arte, mas o objetivo não é conhecer a sociedade. Mesmo que às vezes caia no empiricismo, no fetichismo, tem utilidade para quem quer fazer outra coisa. Não é o que me apraz. Meu objetivo é estudar a sociedade, que é um negócio muito complicado, você não pode estudar holisticamente. Você tem que... eu não diria fatiar, mas escolher pontos de observação. E um ponto de observação fundamental, porque toca em coisas às vezes invisíveis, é justamente o campo artístico, seja lá o que for arte. Então, acredito na história artística do social. O que isso significa? Que a sociedade tem várias dimensões, entre as quais a cultura. Isto é, a cultura é uma dimensão do social, e não o social uma dimensão da cultura.

Não sei se os antropólogos estariam de acordo.

- Acho que não, mas acho que resolve uma porção de problemas. Cria outros, mas não para mim.

Entendi qual é o seu ponto, nessa distinção. Mas, vamos voltar um pouco. Você ficou dois anos e meio, entre 1961 e 1964, na Grécia...

- Trabalhando como arqueólogo. No primeiro ano, visitei mais a Grécia. Meus colegas franceses, que chegaram junto comigo, eram muito interessantes, e a gente viajou muito juntos. No segundo, como já estava redigindo a tese, diminuí. Redigi a tese na Grécia e voltei para a França com o tempo exato para defender.

E quando você voltou ao Brasil?

- Cheguei no dia 31 de março de 1964. Eu voltei de navio, porque tinha muita bagagem - livros, papéis etc. e tal - e foram 11 dias de viagem. E quando a gente estava no meio do Atlântico, recebíamos telegramas, o famoso comício dos marinheiros, e eu... “Meu Deus! O que é isso que está acontecendo?!”. Não entendia nada. Eu tinha passado tanto tempo fora, não é?

Você não estava informado sobre o que estava acontecendo no Brasil?

- No final da minha temporada na Grécia, já sabia que estava meio bagunçado... A primeira perspectiva que meu pai teve da situação, e logo depois do golpe, era a de um jurista tradicional. Ele dizia: "Está uma bagunça", e me mandava recortes de editoriais do Estadão. Minha irmã, que estudava então na Maria Antônia, que foi foco de agitação da USP nesses anos, ${ }^{2}$ me mandava recortes do Brasil urgente, do frei Carlos Josaphat, de quem a gente é grande amigo. Então, as duas coisas não batiam. Meu pai depois mudou de opinião, quando viu o que era 
mesmo. E eu só vim a entender depois de algum tempo, porque realmente foi um baque.

Você chegou no olho do furacão... Você já tinha uma perspectiva de trabalho ao voltar?

- Eu ainda estava na Grécia quando o titular de história antiga e medieval, que era o Eurípedes Simões de Paula, me convidou: "Quando você voltar, vem trabalhar com a gente". Naquele momento, o catedrático é que montava sua equipe. Havia pouca gente - estou falando da Faculdade de Filosofia - que era enviada para o exterior para completar a formação. Então, eu já tinha os trunfos na mão.

Quem era o professor Eurípedes Simões de Paula?

- Ele foi importantíssimo na USP em geral, na Faculdade de Filosofia, da qual foi diretor por duas vezes, e no Departamento de História, onde foi aluno do Braudel e seu sucessor.

Fale-nos um pouco do contexto da USP quando você volta. Qual o peso da história antiga, nesse periodo, no Departamento de História? E nesse contexto tão conturbado politicamente.

- Eu diria, para começo de conversa, que sendo, neste momento, um departamento menor e ainda em formação, era fantástico o convívio com os professores, a gente podendo combinar uma série de assuntos comuns. E isso trazia benefício inclusive para a formação dos alunos e até, eu diria, para certa coincidência de ação política, que tinha que ser feita com cautela. Participei com muitos desses colegas de passeatas e reuniões, se bem que não tanto em 1964, mas de 1968 em diante. Mas diria que, do ponto de vista da periculosidade de certas disciplinas, aos olhos dos militares a história antiga não tinha problemas. Com a história do Brasil já era um pouco diferente; a sociologia já era bem mais visada.

E do ponto de vista acadêmico, qual o perfil da história antiga?

- Você ainda tinha um resquício do que antes era a área de história antiga e medieval, em que havia muito bons medievalistas. O próprio Eurípedes, por exemplo, foi fundamental na faculdade, no departamento e mesmo na história antiga, mas ele não era propriamente um pesquisador de história antiga. Eu voltei do doutorado e era um dos poucos doutores do departamento. Além disso, trouxe também a novidade de trabalhar com fontes que eram diversas daquelas a que se estava acostumado. Isso me ajudou, inclusive, a desenvolver, pouco tempo depois, o projeto de um museu de arqueologia. Agora, pensar o lugar da história antiga na formação do historiador, para mim, foi uma preocupação que tive mais 
tarde. No começo, eu estava entusiasmado com aquilo que havia visto, então, dava cursos belíssimos sobre o santuário na Grécia antiga. Tinha gente que ficava emocionada, mas do ponto de vista da formação, não sei se isso trazia um aporte significativo.

\section{Qual o lugar, afinal, da história antiga na formação do historiador?}

- O Moses Finley, como bom americano, mas trabalhando na Inglaterra, dizia: "Olha, eu não consigo contato com meus colegas de história antiga; muito menos para uma conversa de historiador. Tenho essa conversa com os historiadores da modernidade ou da contemporaneidade. Se quero falar sobre escravidão, não é com um especialista em escravidão na Grécia ou em Roma que vou ter algum benefício, mas é falando com os demais”. No começo, existia uma visão enclausurada da história antiga também na USP. Mas começou a haver aberturas, progressivamente. Com o tempo, percebi que o grande papel da história antiga na formação do historiador se relacionava com a ideia de que a história é a disciplina das diferenças. Isto é, se o que se tenta entender não é tanto o passado, mas, pelo passado, a dinâmica da sociedade, isso significa que a diferença é o que conta para você percorrer esse caminho. No caso das sociedades antigas, ainda com uma vantagem: elas parecem muito próximas, principalmente a Grécia quando você pensa em instituições políticas, arte - mas se a gente for examinar de perto, não são. Então, eu diria que a história antiga cria a oportunidade de se entender o que são as sociedades em seu funcionamento e transformação, de entender a própria historicidade. O Paul Veyne dizia: “A história é o repertório das diferenças". Nessa perspectiva, a história antiga tem um papel fundamental.

Você disse a pouco que a experiência no exterior o ajudou na concepção de um projeto de museu, quando você retornou ao Brasil. Como foi isso?

- Com relação a isso, houve outro fato. Em 1963, o Cicillo Matarazzo ${ }^{3}$ conseguiu uma doação de quase 400 peças arqueológicas, etruscas e romanas, por intermédio do Museu Pigorini, um museu de pré-história e etnografia de Roma. Essa coleção foi doada à USP, que queria fazer um museu arqueológico. Havia uma comissão com gente muito importante - o próprio Eurípedes era o presidente, o Paulo Duarte e algumas outras personalidades -, mas que não sabia muito bem o que fazer. Pensavam em uma espécie de coleção didática, para ilustrar aulas de história da Grécia, história de Roma. Mas ilustrar, sem maiores pretensões. Eu disse: "Vamos fazer um museu disso daqui". E comecei a projetar...

Mas em 1963 você ainda estava na Grécia, certo?

- Eu ainda estava na Grécia quando, um dia, recebi um telegrama do Cicillo Matarazzo dizendo: "Você não quer me ajudar nesse projeto? Se quiser, me 
encontre em Roma dia tal. Todas as despesas pagas". Fui responder a esse telegrama e, inclusive, esqueci que "todas as despesas pagas" incluíam o próprio telegrama. Passei alguns minutos cortando palavras, para dizer que eu aceitava, mas de uma forma não muito brusca. E no correio, na Grécia, disseram: "Mas tem mais umas 200 palavras aqui à disposição". Fui para a Itália e entrei em contato com o Cicillo e o Peregrino Sestieri, diretor do Museu Pigorini, que estava envolvido nesse intercâmbio e que havia agenciado a escolha de peças de vários museus italianos. Eu vi essas peças, dei sugestões, imaginando, efetivamente, que podia ser o ponto de partida para um museu.

\section{E qual era a ideia do Cicillo?}

- A ideia do Cicillo era de um museu, mas ele não sabia muito bem como seria. O Cicillo inventou inúmeros museus. Quase todos deram certo. Na USP, foram dois: antes do meu, o Museu de Arte Contemporânea. ${ }^{4}$ Aliás, foi o Walter Zanini, primeiro diretor do Museu de Arte Contemporânea e com quem convivi no Instituto de Arte e Arqueologia - ele estava terminando a tese dele e eu começando a minha - que deu meu nome para o Cicillo.

\section{E como você imaginava montar o museu com as peças doadas?}

- Eu estava pensando grande. Imaginava que teria sentido um museu que incluísse aquilo que então eu chamava, de uma maneira um pouco idealista, de herança do Velho Mundo - compreendendo não só as sociedades clássicas, mas também Egito e Médio Oriente -, e também a herança pré-colonial, que envolvia coisas que existiam na USP em outros museus, como é o caso da arqueologia brasileira. Além disso, o museu deveria incluir também a herança da América pré-colonial - prefiro falar pré-colonial, e não pré-colombiana, por uma série de razões -, e finalmente, a herança africana. Então, as três raças. Eu pensava assim.

\section{É uma imagem bem tradicional.}

- Eu pensava assim, mas não me arrependo. Não me arrependo porque, realmente, isso serviu para ampliar a coisa. Mas foi uma briga danada com a tal comissão! Eu fiz um projeto para o museu, porque sabia como a coisa funcionava. Eu havia trabalhado em museus: primeiro o Louvre, no período daquela preparação para Atenas, e depois na reserva técnica do Museu de Delos. Quando propus que o museu tivesse uma biblioteca, todo mundo, a começar pelo Paulo Duarte, dizia: "Para que duplicar a biblioteca do Departamento de História?". Eu precisei demonstrar que precisava. Também precisei mostrar a necessidade de pessoal próprio. Disseram: "Pessoal próprio?! Mas e os professores de história antiga?”. Foi uma briga danada! Quando voltei, o museu tinha acabado de ser 
instalado. Começou se chamando Museu de Arte e Arqueologia, ainda um pouco na tradição francesa. O Eurípedes era o diretor, mas ele me disse: "Eu estou diretor, mas, enquanto for diretor, quem vai dirigir é você."

Mas, depois, você assumiu a direção do museu. Quando foi isso?

- Em 1968, ele disse: "Essa situação está insustentável. Vamos formalizar?”. Nós fomos conversar com o reitor de então, que era o Hélio Lourenço de Oliveira. Em 1968, data que a gente não pode esquecer, o Hélio disse: "É pra já", e me nomeou. Dali a 30 dias, Hélio Lourenço de Oliveira foi cassado. Cassado não, aposentado pelo Ato Institucional $\mathrm{n}^{\circ} 5$. Foi um reitor extraordinário. $\mathrm{O}$ que ele resistiu às diversas pressões naquele momento! Mas acabou se tornando uma persona non grata para o governo militar, e precisou sair.

Como diretor do museu você permaneceu vinculado ao Departamento de História? E como foram os primeiros tempos, de organização do museu?

- Sim, continuei na história antiga, com o Eurípedes, inclusive aproveitando o museu para as aulas. Mas para funcionar efetivamente, conseguir pessoal técnico, foi difícil. Eu organizei os primeiros concursos. Trouxe gente muito boa, como o Mariano Carneiro da Cunha, que era especialista em Médio Oriente, a Haiganuch Sarian, que também havia frequentado a Escola Francesa, a Vera Coelho, que havia trabalhado no Peru... As primeiras coleções mesopotâmicas foi Mariano que conseguiu, mas ele já começara, sobretudo, a se interessar por arte afro-brasileira, e foi o primeiro responsável por aquele segmento que eu havia projetado. Quer dizer, no fundo, essa história das três raças, ou das três heranças, valeu para os outros entenderem o que se podia fazer. Então, tinha sentido você ter aquela coleção, não apenas para servir aos objetivos didáticos imediatos, mas para manter institucionalmente um museu desse tipo, aberto ao público, que não existia na USP.

A partir daquela coleção que veio da Itália, você conseguiu articular a convergência, para esse museu, de outros acervos. De onde vieram os acervos africano e pré-colonial?

- Aí foi depois que eu voltei. No caso da tal herança pré-colonial, fiz um projeto de integração das áreas de arqueologia da universidade. Onde existia arqueologia brasileira? No Museu Paulista, que ainda tinha um certo ar de museu enciclopédico, embora a geologia, a botânica e a zoologia tivessem saído na década de 1920; no Instituto de Pré-História, que eu cheguei a dirigir também, junto com o Museu de Arqueologia; e na Coleção Plínio Ayrosa, que era uma coleção de etnografia indígena, na Faculdade de Filosofia. ${ }^{5}$ Fiz um projeto de integração dessas áreas: as coleções, bibliotecas, laboratórios, pessoal e assim 
por diante. O Miguel Reale, que era o reitor, aceitou, mas o Conselho Universitário não viu sentido. Aí entrou o Paulo Duarte, por causa do Instituto de Pré-História, que ele havia criado, dizendo que eu ia destruir o Instituto, que eu era ambicioso etc e tal. Disse até "eu duvido inclusive que ele tenha mesmo esse doutorado".

Então essa tentativa de unificação dos acervos provocou um conflito?

- Pois é, mas o interessante é que a primeira vez que eu falei com o Paulo Duarte sobre o projeto, ele disse: "Fantástico!”. Aí fui falar com o Mário Neme, que era o diretor do Museu Paulista, que respondeu: "Fantástico!”. Só que quando o Mário Neme soube que eu tinha falado com o Paulo Duarte e vice-versa, tudo melou. Os dois eram inimigos. Esse projeto levou 21 anos para ser realizado. O reitor de então, José Goldemberg, que estava no Conselho Universitário quando o projeto foi apresentado pela primeira vez, disse: "Olha, achei aquele projeto bom. Vamos botar para frente?”. Ou seja, depois que o projeto atingiu a maioridade, fui o responsável por implementá-lo, encaminhando o material arqueológico para o MAE, que já era então um museu de arqueologia e etnologia. Nessa época, assumi a direção do Museu Paulista, que, por sua vez, teria que virar um museu de história. Essa foi a minha segunda virada com museus.

Vamos falar sobre o Museu Paulista, mas é importante situar porque você dirigiu o Museu de Arqueologia e Etnologia por dez anos e depois houve um longo periodo, entre o final dessa atuação e a direção do Museu Paulista, que você assumiu em 1989.

- Mesmo saindo do Museu de Arqueologia, continuei a me interessar por museus, a participar de encontros. Quando o Goldemberg se lembrou do projeto, me nomeou como relator da comissão encarregada de propor a integração das áreas de arqueologia e etnologia da universidade. Agora, uma vez que eu assumi o Museu Paulista, no contexto dessa integração - o que significa que saiu muita coisa para o Museu de Arqueologia e Etnologia -, o que restou devia ser transformado em museu histórico. Aí propus o plano diretor, que na época também foi uma novidade. "Mas plano diretor?! Precisa?" Precisa. Consegui reunir muita gente para discutir esse plano diretor, gente da USP e de fora, de áreas como artes e urbanismo. E o mais interessante é que pela primeira vez o pessoal do Museu Paulista, que ainda estava dentro de uma certa tradição de museu histórico, que vinha do Taunay, da década de 1920, pôde discutir essas questões. ${ }^{6}$ Era novidade, porque não se discutia o que eles faziam, o porquê de se fazer daquele jeito, se existiria outro tipo de proposta e assim por diante. Pela primeira vez, o pessoal do museu, nessas reuniões preparatórias do plano diretor, teve a oportunidade de se manifestar. 
Quais as principais propostas inseridas nesse plano diretor?

- O plano me guiou durante meus quatro anos de gestão. No primeiro momento, era o seguinte: "Nós vamos organizar um museu de história. Um museu de história não é o correspondente visual de um manual de história, portanto, o objetivo do museu não é ensinar história”. Se você quiser aprender história, no sentido inclusive de narração, de marcos do passado, pegue um bom manual. Mas o museu pode mostrar a historicidade das coisas, que as coisas são historicamente contingentes. O museu de história tem a grande missão de ensinar a historicidade do mundo material em que estamos mergulhados. Ele trabalha com essas mediações sensoriais, então, é nesse sentido que se deve investir. Ele precisa ser um museu de cultura material, mas não para você ter séries de artefatos e dizer, "olha, os artefatos de cozinha conhecidos eram esses e esses". Isso é uma base, um ponto de partida para você trabalhar problemas históricos. A primeira coisa que precisei discutir foi se o museu de história deve ser um museu de problemas históricos ou de coisas históricas. Outra questão diz respeito à distinção que a gente tem que fazer entre documento histórico e peça histórica. Quando você tem a mesa de jogo do padre Feijó, ela costuma ser tratada como objeto histórico, não como documento histórico. Mas acontece que dá para você fazer as duas coisas, inclusive porque o fato de ela ter se transformado em um objeto histórico já é um problema histórico que você pode explorar. No museu, a fetichização é corrente. Mas, em vez de dizer "vamos eliminar a fetichização", você a trabalha também como um objeto de estudo, para entender por que e como a gente fetichiza, e o que isso significa historicamente.

Como essas preocupações mais teóricas se traduziram na organização do acervo?

- A primeira perspectiva foi de que não devíamos partir da coleção, mas sim do problema (porque antes só se pensava em coleção). Então, foram definidas as três linhas mestras que estão no plano diretor: história do cotidiano; história do mundo do trabalho, e - como a gente tinha uma belíssima coleção de telas e desenhos - história do imaginário, isto é, como a história vira imaginário visual. Definimos também um corte cronológico, porque senão não daria para trabalhar, que seria mais ou menos de 1850 a 1950 . Com relação às telas, há uma coisa gozadíssima. A primeira grande pinacoteca de São Paulo foi a do Museu Paulista, ainda no século XIX, e quando, em 1904, se organizou a Pinacoteca do Estado, quem é que forneceu a primeira coleção de telas? O Museu Paulista, que mandou para lá as telas de "tema artístico", ficando com as "de história". Se vocês pensam que foi só em 1904 que esse critério valeu, não. Quando o próprio Sérgio Buarque era o diretor, mais tarde, uma nova leva foi enviada e de novo se disse: "Tela de tema histórico fica aqui e tela de tema artístico vai para lá". Quer dizer, se tirou a historicidade da arte e a artisticidade da história. Então, eu disse: "Uma exposição como essa não é 
para você saber como é que as monções partiam no rio Tietê, ou como é que a cidade de São Vicente foi fundada", que são as telas que existem lá, "é para a gente saber como é que, na virada do século XIX para o século XX, a história virou imagem". Esse é o sentido de um museu histórico. Senão, pega um manual ou um livro com boa ilustração. Se é para ter um museu, é para a gente estudar dessa perspectiva.

\section{E essa proposta deu certo?}

- Houve certa dificuldade de entendimento no início, mas deu certo e esses três vetores estão se desenvolvendo. $\mathrm{O}$ vetor do imaginário é o menos desenvolvido. Porque há uma coisa interessante: ainda continua essa divisão entre pintura histórica - que, aliás, é um gênero pictórico - e pintura artística, e quando se trabalha a pintura histórica, não se trabalha dentro da história da pintura, mas como alguma coisa à parte. Seria necessário reenquadrar o que é tema histórico dentro da história da pintura. Historicizar a pintura do século XIX, por exemplo, ou do começo do século XX, e não ter um critério puramente formal, como o do gênero. Isso ainda não foi suficientemente trabalhado. Mas nas outras áreas, a coisa vai bem.

\section{O Museu Paulista é considerado um museu de referência, com grande circulação de} público. A que você atribui isso?

- E um lugar de referência muito forte. Para começar, você tem que entender que foi o primeiro museu de São Paulo. Aliás, é um dos quatro mais antigos do país, junto com o Museu Nacional, o Museu Goeldi e o Paranaense. Quando se falava em museu em São Paulo, tinha que ser o Museu Paulista. Em segundo lugar, há uma associação fortíssima com a independência: "Foi lá que o negócio aconteceu". Essa marca é absolutamente fundamental. Aliás, foi fundamental para que existisse o próprio museu, que não foi concebido como museu, mas como monumento. O projeto de monumento surgiu logo depois de 1822, mas não deu certo, porque não havia verba. Até que, no último quartel do século, se pensou em loteria: a Loteria do Monumento conseguiu arrecadar verba suficiente e houve um concurso interessantíssimo, todo cheio de peripécias. $O$ projeto vencedor foi um edifício que reproduzia um monumento renascentista de Vignola, um palácio. Não era um edifício que devesse ter alguma serventia, mas funcionar como ponto de referência para um evento. Porém, como a Comissão do Monumento era constituída em grande parte por positivistas e o problema da educação era uma bandeira, logo se começou a pensar: "Ah! Vamos transformar em escola". A primeira reação das autoridades foi dizer: "Não dá. Porque fica na beira da serra do Mar, então, vêm os ventos frios e úmidos do sul e aí as crianças vão ficar roucas". Então, não dava para escola. "O que a gente faz? Ah! Museu”. E aí se criou o Museu do Estado, com uma primeira coleção. 


\section{Uma primeira coleção de que tipo?}

- De história natural. O primeiro diretor foi um ilustre zoólogo, portanto, o museu se desenvolveu nessa área. Mas tinha uma parte que era a celebração. É interessante porque você tinha dois estatutos operando no museu: um estatuto cognitivo, consubstanciado nos espécimes vegetais, geológicos e zoológicos, que você descrevia e classificava; e um estatuto afetivo, ligado aos objetos celebratórios. No regimento do museu, estava até prevista uma ala para "bustos de mármore de pessoas ilustres". Você tinha o estatuto cognitivo e o afetivo convivendo em perfeita tranquilidade. Mais tarde, quando se desenvolveram as coleções de antropologia e etnografia, você teve outras convivências extraordinárias. Por exemplo, o índio da tela histórica convivia com o índio da etnografia, embora fossem perspectivas totalmente diferentes: o índio da etnografia tinha fornecido documentos; o índio da história tinha fornecido matéria-prima para a ideologia. Além disso, você tinha o bandeirante, que era o caçador de índios, numa fraternidade extraordinária com sua presa, dentro do mesmo espaço físico. Então, quando assumi, disse: "A gente vai ter que pensar essas coisas".

Gostaria de discutir a dimensão pública do museu a partir dessa distinção entre cognitivo e afetivo. Acho que o Museu Paulista é próprio para se falar disso, exatamente por ser um ponto de referência do paulistano. Você sentiu algum tipo de reação quando sugeriu uma revisão da concepção do museu? Como o público reagiu?

- Em primeiro lugar, como você disse, o museu é uma referência, mas não só monumental; é também um lugar de sociabilidade. Embora esses lugares de sociabilidade tenham se multiplicado na cidade, o museu continua a ser frequentado em fins de semana. Eu diria até que existe uma espécie de religião cívica, de que falam os americanos, por exemplo, que não é tão forte como já foi, mas que ainda persiste. É perceptível no mês de setembro, quando a visitação aumenta consideravelmente. Na Semana da Pátria, então, você nem imagina! É tradição, para certo tipo de público - e que não é um público de elite -, visitar o Museu Paulista, como se fosse um ritual necessário de celebração da sua própria identidade. Essa ideia de nacionalidade é alguma coisa que está presente lá, efetivamente. A própria sala em que se encontra a tela do Pedro Américo é visitada como se fosse uma capela ou uma igreja, e você vai lá prestar sua devoção. Quando os sarcófagos do D. Pedro e da esposa foram retirados do monumento que se encontra no jardim, e colocados no Salão Nobre do museu, alguns visitantes chegavam lá e se persignavam. Então, essa religião cívica existe mesmo, e precisaria ser objeto de um estudo. Bom, então, a primeira questão é essa: o museu ainda faz parte do referencial afetivo da cidade. Em segundo lugar, o museu funciona como museu - quase todo escolar visita. A impressão que se 
tem é que a visita faz parte do calendário escolar, aliás, o número maior de visitantes é de escolares. Mas não sei para que serve essa visita, porque você vê aquelas centenas de meninos e meninas com seus caderninhos, que entram no museu e fazem o quê? Copiam as legendas. Parecem caititus, aqueles porquinhos-do-mato que têm uma consolidação na cervical e não podem levantar o pescoço. Eles não veem o que está acima da legenda. Então, o que isso significa? Que se mantém a tradição logocêntrica da formação. Eles foram alfabetizados, como o termo indica, apenas com as palavras. E isso se manifesta no museu, em que você teria a oportunidade de utilizar outros códigos, outros sentidos, que precisam ser trabalhados. Porque o que a gente tem de universal, do ponto de vista fisiológico, é o aparato perceptível, mas o uso desse aparato é histórica e culturalmente mutável. A grande oportunidade de aprendizagem seria no museu. No entanto, o que se faz é reproduzir - eu diria, de uma forma até pervertida - essa limitação da escola.

\section{Como seria possível enfrentar esse problema?}

- Sempre pensei que a gente tem que trabalhar com os professores. Comecei, inclusive, a organizar cursos para professores guiarem as suas turmas e avaliarem depois a visita, o que só pode ser feito em pequena escala. Não é a escala da necessidade, mas é alguma coisa que tem que começar pequeno e depois pode crescer, os professores podem eles próprios se organizar para multiplicar essas experiências orientadas. Agora, você perguntou se as alterações propostas na organização do museu trouxeram grande repercussão. Não trouxeram, justamente por essa questão do uso que se faz do museu, pelo seu baixo aproveitamento. Acho que a única reação, que no começo foi negativa e depois se tornou positiva, foi quando repintei a parte externa do museu, que estava bastante deteriorada. A gente fez estudos, com o Instituto de Pesquisa Tecnológica (IPT), com o Iphan e o Condephaat, ${ }^{7}$ para saber qual era a cor original, e conseguimos uma cor que era diferente daquela a que o público estava acostumado. Muita gente disse: "Essa não é a cor da minha infância". Não era, efetivamente, mas a cor da infância não era a cor do final do século XIX, que era uma espécie de rosa, mas um pouco amarelado. Disseram: "O museu está com icterícia”.

Considerando sua experiência nesses dois museus da USP, você veria uma diferença entre museus universitários e outros museus?

- Vejo, pelas vantagens que você tem de pertencer a uma universidade. Essa é a primeira afirmação. De certa maneira, enfraquecida pela segunda: as universidades não têm sabido aproveitar essa vantagem, e nem os museus. Porque quando penso em um museu universitário, não estou pensando em um museu para a universidade. Mas já que está na universidade, ele vai ter muito mais 
condição de assumir todas suas responsabilidades. Para mim, o museu tem objetivos que são de natureza científico-documental, cultural e educacional. Principalmente no que se refere ao científico-documental, ele já teria o respaldo da universidade. Por outro lado, a universidade teria condições de se beneficiar diretamente, usando o museu como uma possibilidade de socializar o conhecimento produzido. Eu penso, por exemplo, em um departamento de história e um museu de história. Se o museu de história tem como foco justamente a cultura material, isso significa que há uma faixa de questões que poderia se incorporar ao departamento. Mas não há interesse, e as coisas continuam segmentadas. Quando, por exemplo, o pessoal do museu é convocado para cursos no departamento, são cursos que ignoram aquele aporte específico que o historiador de museu poderia trazer para a história como disciplina. Então, é como se o museu fosse uma espécie de apêndice, e não como se fosse um centro produtor de conhecimento histórico. Aí preciso dizer uma coisa que acho importante: não imagino que deva haver uma história da cultura material, porque aí não é história, é história documental, é história de fonte. Você estaria confundindo a fonte com o problema. Você faz a história das meias, das escovas de dente, do que quer que seja. Numa escala de qualidade superior, é o trabalho do Daniel Roche, por exemplo, que tem que ser feito. Mas, para mim, a cultura material deve dar conta da dimensão material de qualquer segmento da vida social. Em todos os segmentos da história há uma dimensão sensorial: na história econômica, na história política, na história institucional, na história das minorias, das maiorias, seja lá o que for. Então, a ideia de uma história à parte do material, para mim, desfigura a natureza do problema histórico. Nessa perspectiva, tanto o trabalho do museu quanto o do departamento de história teriam que estar articulados. Eu diria até se existe uma percepção da importância do que se faz no departamento a partir do museu, o inverso não ocorre. Porque se imagina que, no museu, o que se faz é estudar artefato. $\mathrm{O}$ artefato é o documento; o que você estuda é a sociedade. O artefato está no jogo social, e esse jogo social tem que ser entendido em todas as dimensões e a dimensão material é uma delas.

\section{A tradição de uma história da cultura material estaria ancorada lá atrás, nos estudos clássicos?}

- Não, absolutamente. Em primeiro lugar, a história da cultura material seria uma coisa mais recente. A própria ideia de cultura material surge na antropologia, com os estudos feitos nos quadros da dominação colonial europeia. Então, era um registro sobre os povos colonizados. Isso marca muito a própria feitura das coleções e o uso que se fez posteriormente. Você precisava documentar essas sociedades por intermédio dos seus artefatos. Sem contar que havia uma 
perspectiva muito marcada, evolucionista, que facilitava até mesmo uma ideologia colonial. Começa aí a surgir a atenção pelo estudo do artefato, e é por isso que a antropologia cultural surge ligada a museus. É mais tarde que ela vai se deslocar para a universidade.

Essa atenção aos artefatos foi enfatizada pelo difusionismo, certo?

- Certo. Agora, quando surgem outras abordagens, sobretudo, quando estoura o estruturalismo, o museu deixa de ter a mesma relevância. $\mathrm{O}$ estruturalismo, em princípio, não precisa de museus, porque se quiser falar de mito, você precisa da palavra. É outro tipo de registro. Quando os objetos voltam à cena, já mais tarde, é numa outra perspectiva. Apesar de a Escola dos Annales, antes disso, ter dito "é documento tudo aquilo que pode responder a uma pergunta", a ideia de que existem documentos de primeira e de segunda classes é vigente ainda hoje. A última publicação que eu recebi sobre a matéria, da Routledge, de Londres, que é uma grande editora, é uma série sobre fontes para o estudo da história lançada em 2008. Nessa série, há um volume que se chama Fontes alternativas para o estudo da história, onde se encontra a cultura visual e a cultura material. Ainda se fala, portanto, em "fontes alternativas". Sem contar que o problema não está nas fontes. O estudo da cultura material não é o estudo das fontes materiais. A natureza do problema histórico é que vai configurar a materialidade a ser trabalhada. Para isso, supõe-se que as fontes materiais tenham alguma coisa de específico a dizer, mas não se trata de fazer história dos documentos, história de fontes.

Como você explica, ainda hoje, esse estatuto "alternativo" ou "secundário" atribuído às fontes visuais e materiais?

-O que acontece é o seguinte, o historiador nasce logocên trico. A formação que ele tem, desde o ensino fundamental, é baseada na palavra. E mesmo no curso universitário continua sendo a palavra. $\mathrm{O}$ historiador não tem aquilo que o antropólogo e o sociólogo têm, que facilita sair desse universo logocêntrico, que é a pesquisa de campo. A pesquisa de campo do historiador é no arquivo, mas não se compara com a pesquisa de campo do antropólogo. A do sociólogo já é um pouco diferente, mas também exige contato com o empírico. Já a história é abstração. Você trabalha com os tais ideais-tipos; você não trabalha com classes sociais em ação. Classe social não existe, a não ser como abstração, para você entender certo tipo de interação. Mas o historiador não pensa a abstração como um recurso heurístico; pensa que é $o$ histórico. Não é. É um instrumento pelo qual você consegue produzir o seu conhecimento. $\mathrm{O}$ historiador não está acostumado com o empírico. Eu tive a percepção bem nítida disso com um grande historiador que eu respeito muito e é um amigo, que visitando casas operárias associadas 
à primeira revolução industrial na Inglaterra dizia: "Mas então eram assim?!”. Quer dizer, ele conhecia tudo sobre a Revolução Industrial, menos como é que, no empírico, a coisa se passava. Então, uma coisa é você falar sobre habitação operária lendo Engels e outra coisa é você saber, concretamente, o que é o habitar operário.

Você diria que essa falta de familiaridade do historiador com o empírico está na origem do fascínio pela imagem, mais precisamente, a imagem fotográfica, como se ela pudesse abrir uma janela para o empírico a partir da sua relação com o referente?

- Eu diria que sim, não pelo interesse histórico, mas pelo atributo do exótico. Quando você descobre a dimensão do empírico, é como se fosse uma coisa de outro mundo, mas não daquele mundo que você estudou. Estabelecer a articulação demora algum tempo. Eu vejo muito mais como uma reação externa, pelo exótico: “Como é que eu nunca imaginei isso?!”. Não é como se você dissesse: "Ah, aqui eu vou encontrar um tipo de historicidade que eu não encontrei em outros documentos". Acho que esse raciocínio faz parte do fascínio a que você se referiu, mas estou dando uma resposta puramente subjetiva e intuitiva. Agora, interessante é justamente essa marca do logocentrismo, inclusive quando se trabalha a visualidade.

Você poderia desenvolver um pouco mais sobre a dificuldade de apreensão da visualidade como um atributo específico?

- Em primeiro lugar, eu diria que a palavra e a imagem são dois sistemas diferentes de apreensão do mundo empírico. Depois, existe a noção de que imagens e coisas são linguagens, mas não são linguagem coisa nenhuma; têm potencial linguístico, o que é outra conversa. Por exemplo, o martelo não integra uma linguagem. Se o martelo fosse componente de uma linguagem, eu não poderia pregar um prego, porque não estou emitindo mensagem nenhuma. Agora, o martelo pode ser usado em um contexto linguístico. Você pega o martelo e diz: "Representa o trabalho operário", bota a foice e se completa. Mas não é para isso que se inventou o martelo. Essa desmaterialização das coisas materiais e essa desvisualização das coisas visuais, nessa concepção, justamente, de que objetos e imagens são componentes de linguagem semelhante à articulada, como a linguagem verbal, comprometem absolutamente o entendimento do jogo social de que participam coisas e imagens. Se você vai usar a imagem como ilustração daquilo que lhe foi fornecido por fontes verbais, você não vê jogo nenhum, porque aí o que conta é a representação, é o discurso sobre a coisa e não a coisa funcionando como discurso. Em suma, as coisas e as imagens (que são coisas), não podem ser reduzidas a representações, mas devem ser consideradas na sua efetiva agência, que entendo como potência de ação. 
Você acha que há uma forma de apropriação, pelo historiador, desse tipo de material a partir do instrumental da história ou é preciso lançar mão de outros instrumentais, como a semiótica?

- Permitam-me fazer uma distinção. Você pode usar aquilo que for capaz de esclarecer alguma coisa. Tenho muita desconfiança, não tanto da semiótica, mas dos semióticos, mas não descarto a semiótica. O que eu pergunto é que função deve ter a semiótica ou qualquer outro recurso, de dentro ou de fora? É para formular questões, não para ter as respostas. O problema existe quando você procura, na semiótica, por exemplo, as respostas. Não dá certo. Mas se você ampliar o seu horizonte de indagação pode ser fantástico. Vejamos uma grande discussão com relação a duas questões: no campo da história, o anacronismo, e no campo da arqueologia ou mesmo da antropologia, a analogia. Quanto ao anacronismo, é condenado você partir da sua própria experiência para indagar o passado: “Isso não se faz!". Eu acho que deve ser feito, mas sabendo que você vai encontrar coisas diferentes, jamais para lhe dar uma resposta. Se você está estudando escravidão, parta daquilo que sua própria experiência sobre a organização do trabalho lhe traz, mas sabendo, a priori, que a resposta tem que ser diferente, porque senão você não está fazendo história. Para mim, o anacronismo é, sim, um recurso heurístico. Nos meus cursos de leitura, eu pegava um texto que falasse, por exemplo, de um problema de natureza religiosa. Antes pedia o seguinte: vamos partir da nossa experiência, para saber qual é o quadro de fenômenos religiosos que a gente tem que examinar. Posso considerar a religião do ponto de vista da crença - a crença como conceito, como teologia, como um tipo de relação subjetiva com o transcendente, seja lá o que for. Mas também tenho que pensar nas práticas. Depois tenho que pensar na ética, tenho que pensar no aspecto institucional, que envolve o econômico e por aí vai. Tenho que pensar em uma porção de coisas que a minha experiência traz, ela me ajuda a formular perguntas. Eu vou examinando o texto e percebendo as diferenças. Eu posso estar estudando uma sociedade em que o problema da crença não existe: Roma. Por isso disse que há um aspecto instrumental no estudo da Antiguidade: para você ter um modelo que pode ser contraposto ao da sociedade, vamos dizer, pós-século XVIII.

Vamos sair um pouquinho da teoria e voltar para o biográfico. Sua trajetória é marcada por um trânsito entre o mundo acadêmico e o mundo das instituições. Isso me fez pensar no Darcy Ribeiro, professor como você, antropólogo, que criou o Museu do Índio, o Memorial da América Latina, universidades, CIEPs etc. Darcy valorizava fortemente a intervenção dos intelectuais nas questões da sociedade, e criar instituições é uma forma importante de intervir. Você se vê nessa perspectiva?

- Não exatamente nesses termos, mas semelhante. Aliás, aproveito para dizer que fui grande amigo do Darcy. Eu o conheci quando ele fez o projeto do 
Museu do Homem, lá em Belo Horizonte. Um dia, apareceu alguém lá no Museu de Arqueologia e a secretária foi me chamar, dizendo: "Tem um tal de Darcy aí que quer falar com o senhor. Ele disse que foi ministro, mas não parece não".

\section{O Darcy estava projetando o Museu do Homem?}

- Ele estava pensando. $\mathrm{O}$ museu foi o ponto de partida e depois a gente teve longas conversas. Para mim, criar o Museu de Arqueologia significou um caminho de socialização da produção acadêmica. Eu não entendia muito bem o que era isso, mas entendia o potencial disso, quer dizer, criar o museu abria uma possibilidade de sair da "torre de marfim". Porque esse é um perigo realmente existente, sobretudo para a área de história antiga. $\mathrm{O}$ museu foi a primeira plataforma para, justamente, como diria o Darcy, intervir na sociedade: produção de conhecimento, formação, aspectos educacionais e culturais, educação de sensibilidade e essas coisas. Era confuso, mas eu já sentia que era um caminho a ser percorrido. Paralelamente a isso, aconteceu uma coisa que me forneceu um segundo caminho. $\mathrm{OEu}$ rípedes era representante do Instituto de Pré-História no Condephaat. Quando assumi o Instituto de Pré-História, ele disse: "Agora você vai ter que participar". Em 1971 entrei no Conselho. E acontece que tanto o universo dos museus quanto o do patrimônio cultural ajudaram a fertilizar minha própria atividade na academia, seja de pesquisa ou de docência. Foram as duas grandes viradas.

\section{A partir dessas experiências, então, você começa a produzir sobre museu e patrimônio?}

- Pois é. É gozado, porque a partir de certo momento, a produção sobre museu e patrimônio vai ser mais importante do que a produção sobre a antiguidade. Essas novas áreas acabaram por exigir novos contatos de todo tipo, principalmente intelectuais, no campo da antropologia, da visualidade, dos estudos de percepção e cognição etc. Às vezes pode parecer que comecei nas letras e cheguei à cultura material, que é coisa muito diferente, mas tem certa lógica, embora não tenha sido racionalmente previsto, não era um projeto. Vejam vocês. Ao trabalhar com o patrimônio cultural, o problema da cidade assume uma dimensão extraordinária, porque a cidade é tudo que você possa imaginar. Eu comecei a me interessar por cidade a partir justamente do estudo de uma cidade antiga e depois incorporei a esse interesse o debate sobre o patrimônio.

Como foi trabalhar no Condephaat, do ponto de vista, exatamente, da intervenção, da definição de políticas para o patrimônio no estado de São Paulo?

- Foi uma grande dificuldade, porque, em 1971, pensar o patrimônio cultural como fato social era uma agressão. Houve até um caso célebre. Iporanga é uma cidade de mineração do século XVIII muito interessante e que, pela po- 
breza, conseguiu resistir do ponto de vista físico, da carcaça. Havia a possibilidade de fazer um projeto de restauração de monumentos, e eu disse: "A gente não tem que fazer um projeto de restauração de monumentos; a gente tem que fazer um projeto de viabilidade e qualificação cultural da cidade". A cidade é um bem cultural, ou seja, ela é uma coisa boa. Boa para você contemplar, fruir esteticamente, visitar. Está certo. Mas tem que ser boa também para você usar, praticar como cidade - deve ser boa para o habitante morar. Pensar a cidade como um bem a ser fruído por quem vem de fora é completamente ilógico. A cidade boa para habitar e culturalmente qualificada tem que ter infraestrutura, esgoto, não é só restaurar o prédio bonito. Tombar a cidade toda, no estado em que ela se encontrava, seria justamente você condenar os habitantes a deixarem a cidade ou a viverem em condições infra-humanas. A ideia de que a cidade é bem cultural se for boa para habitar qualificadamente não foi bem compreendida, e na hora das decisões, se deu para trás. Foi uma das minhas grandes frustrações. Acho que hoje já seria diferente.

Quando você acha que essa perspectiva começa a mudar? Em nivel federal, a literatura enfatiza uma mudança que ocorre no final dos anos 1970, início dos 1980, com a gestão do Aloísio Magalhães.

- Não, a coisa começou antes, no Condephaat. Eu consegui me entender com o Nestor Goulart Reis Filho, que era historiador da arquitetura e foi o primeiro diretor arquiteto da FAU, a Faculdade de Arquitetura e Urbanismo da USP, e nós organizamos o primeiro curso de especialização em conservação e restauração de patrimônio urbanístico. Eu era também muito amigo do Luis Saia, que é um dos heróis fundadores do Iphan, do tempo inclusive do Rodrigo Melo Franco. O Saia estava fora da universidade, mas foi incorporado ao curso, assim como gente muito boa de fora, entre eles o Hugues de Varine-Bohan. Arquitetos de todos os pontos do país, um grupo de umas trinta pessoas, vieram fazer o curso. A maioria já trabalhava no patrimônio e, pela primeira vez, ouviu falar de certas coisas, porque eles estavam engaiolados naquele universo de pedra e cal. O Varine, naquela época, era o secretário do Icom, International Council of Museums. Ele falou de cultura de uma forma que abriu portas, janelas e claraboias para esse pessoal todo. Houve depois uma segunda edição desse curso, já com a intervenção do Condephaat, e a gente trouxe de Bolonha o Pier Luigi Cervellati. ${ }^{8}$ Bolonha, eu acho, é a cidade mais representativa de uma nova mentalidade na renovação urbana daquelas cidades destruídas ou bombardeadas durante a guerra. Muitos daqueles que tinham feito o primeiro curso também fizeram esse, mas havia um público mais vasto, porque já era um projeto do Condephaat. Veio muita gente, não só arquitetos, mas de outras formações, que, pela primeira vez, ouviram falar de renovação social. E o Cervellati dizendo: "Ou se legitima dessa 
forma ou não tem sentido". Eu diria que esses foram dois grandes marcos para o Brasil. Há um terceiro que é aquele projeto do governo federal, o Programa das Cidades Históricas. Para mim, são três referências que permitiram entender que o patrimônio não é uma questão de coisas materiais, não se limita a isso.

Você voltou ao Condephaat, na década de 1990, e há bem pouco tempo teve um terceiro mandato, em 2006 e 2007. Ou seja, você continua atuando na área das políticas patrimoniais.

-E no Iphan também, uma experiência que tem sido muito gratificante. Ainda há inúmeros problemas, inclusive de organização setorial, além de disputas internas. Mas acho que o conselho, que define políticas e linhas de atuação, melhorou muito. É claro que tem uma composição heterogênea. Alguns especialistas já têm uma abertura maior com relação à visão de patrimônio. Existe uma área que ainda é refratária, a do chamado patrimônio material, que continua dominada pelos valores arquitetônicos e formais. Agora, há uma área que eu acho que está nos trinques, e por sorte se criou uma câmara, da qual eu participo, que é a Câmara do Patrimônio Imaterial. Acho que essa, realmente, botou o dedo na pedra para sair água, mel e leite.

\section{Você pode contar um pouco como tem sido essa experiência?}

- Tive algumas experiências notáveis, que me ajudaram a entender melhor certas coisas, inclusive a inadequação na radicalidade de você separar material e imaterial. Os casos em que fui relator me ajudaram muitíssimo. Por exemplo, o tambor de crioula. No relatório, cheguei até a citar Lacan e Kristeva -imaginem só! Vocês conhecem o tambor de crioula? São certas celebrações muito antigas, com mais de dois séculos, em que se dança a partir, justamente, do toque dos tambores. Elas têm um peso religioso muito grande - em geral, celebram São Benedito. Mas a coisa é muito mais vasta e serve de articulação, funciona por bairro... O tambor de crioula tem duas variantes que, segundo a denominação dos próprios grupos de tambor, são o tambor de casa, que os próprios grupos organizam em casas particulares, reunindo toda uma vizinhança, e o chamado tambor de contrato, que, no fundo, é o que vira espetáculo. Portanto, eles próprios têm as duas versões, uma para si e a outra para o público. Mas o que é interessante é que a versão das casas se transforma, quer dizer, essa é que integra o cotidiano deles e tem significação cultural, portanto, muda junto com as outras mudanças todas que ocorrem; a outra é fixa, quer dizer, é um aspecto absolutamente voltado para o consumo. Porque você não pode iludir o consumidor. $\mathrm{O}$ consumidor vem procurar certo tipo de mercadoria e você tem que apresentar aquela mercadoria. Se você muda, o consumidor diz: "Isso não é autêntico, não vou comprar essa mercadoria." Os próprios grupos distinguiram isso. 
E onde entraram as leituras de Lacan e Kristeva?

- Do ponto de vista da cultura material, a distinção, eu diria até ontológica, de um tambor com relação ao outro é muito grande. Aí entram o Lacan e a Kristeva, dizendo que é preciso distinguir a gestualidade pragmática, isto é, a práxis gestual, da gestualidade comunicativa. A práxis gestual não tem função de comunicação. Quem dança não está querendo comunicar nada; é a atualização de uma presença no movimento da dança e no ritmo do tambor. É ação. Eu li alguns depoimentos de pessoas que confirmavam absolutamente isso. Eles ficavam extasiados - é como o êxtase, no sentido etimológico, ékstasis - ao dançar. Houve entrevistas com alguns que tinham largado o tambor por razões de saúde, e falavam chorando: "Eu me sentia outra pessoa". Ou seja, dançar é a maneira de criar uma presença altamente gratificante. Não precisa comunicar nada para ninguém. Não é para ser visto; é para ser praticado. É práxis gestual, dizem os dois teóricos. O outro é a gestualidade expressiva, comunicativa. E isso significa que não é mais uma ação corporal. $O$ corpo não coincide mais com o gesto, o corpo, agora, representa pelo gesto. $\mathrm{O}$ corpo vira um instrumento linguístico. Se você precisa de alguém para ver, vira espetáculo. Essa foi uma das minhas grandes descobertas trabalhando, justamente, no Iphan.

Como essa abertura trazida com o tambor de crioula ajudou você a pensar a distinção entre material e imaterial?

- O que fica claro, justamente, é a inadequação dessa distinção entre material e imaterial. Por exemplo, a dança... Não sei se vocês conhecem aquela distinção que a Margaret Mead faz com relação à dança. A dança clássica, que é a dança ocidental por excelência, seria a negação do espaço. $\mathrm{O}$ dançarino procura negar a lei da gravidade, o que se quer é a leveza do corpo flutuando no espaço. Ela opõe a esse tipo a dança de posse, de domínio do espaço, que ela associa às “sociedades simples". E a dança repetitiva, que, ao invés de procurar negar o espaço, afirma o vínculo de dependência com relação a ele. Então, você bate o pé firme. Ela tem que ser rítmica porque ela precisa dominar pela repetição. A dança do tambor, justamente, é essa do corpo tomando posse do espaço, não o negando, mas se apropriando dele. Ora, eu vejo espaço e corpo como realidades materiais. Eu percebo a imaterialidade dessa dança pelos significados e valores que ela expressa. Mas dentro daquela práxis gestual, a matéria-prima é corpo e chão. Então, quando você fala material e imaterial, o negócio fica complicado. Você tem um Departamento de Patrimônio Imaterial e um de Patrimônio Material, cada um trabalhando numa linha.

E como você definiria patrimônio?

- A gente não escapa das coisas materiais, mas elas não têm valores intrínsecos, não têm nada de imanente que não sejam as propriedades físico-químicas. No entanto, elas têm propriedades de natureza material que permitem externali- 
zar ideias, expectativas, ideologias, memórias, identidades; elas funcionam como mediadoras, como combustível para a intervenção no mundo real. Então, eu diria que elas atuam como uma dimensão de qualificação diferencial - esse diferencial é importante, porque senão tudo vale tudo - do cotidiano e do trabalho.

Esse "tudo vale tudo" me lembrou um texto do François Hartog, que fala sobre a febre patrimonializadora dos nossos tempos, sobre o "tudo é patrimônio". Como é que se mantém uma visão de qualificação diferencial num tempo de febre patrimonial? Tem solução?

- Se tem, eu não conheço, e pago bem para quem tiver. O que eu diria é que vejo a febre patrimonialista de que fala o Hartog como uma necessidade de mercado que se manifesta em várias áreas. Nós estamos vivendo um tempo em que as reivindicações que a gente chama de justiça social - salário, saúde, condições materiais de vida - estão sendo progressivamente substituídas por reivindicações por reconhecimento, reivindicações identitárias. Os casos da Europa, aquelas revoltas de pieds-noirs em Paris, Lyon e Marselha mostram isso claramente. Embora sejam miseráveis ou semimiseráveis, eles estavam queimando carros e procurando, não melhores salários, mas chamar a atenção para a necessidade que eles têm de serem reconhecidos. Nessa perspectiva, a gente vê claramente como, cada vez mais, a cultura passa a ser um álibi. A gente vê isso também na área dos projetos culturais, como, para as empresas, é fundamental dar importância ao universo da cultura. Mas esses projetos culturais são projetos anestésicos - é a visão da cultura como um segmento à parte da vida social. É um segmento nobre e nobilitante, então, é por isso que serve justamente aos interesses do mercado. Quando você fala em cultura como um segmento especial, seccionado do cotidiano e do universo do trabalho, você vai ter produtos culturais, produção cultural, produtor cultural, consumidor cultural, instituição cultural. Estamos falando de mercado, e falar em mercado simbólico é tocar em um dos segmentos do mercado que mais tem crescido. Então, é nessa perspectiva que eu vejo essa proliferação. É só isso? Não! Há outro aspecto, que também está ligado a isso, que alguns chamam de consequência do pós-modernismo, que é a relativização, relativização epistemológica, gerando a ideia de que o conhecimento é um problema de ponto de vista, relativização ética, relativização de valores... Depois há o problema também da sociedade de informação, que satura você de informação, já denunciado pelo Andreas Huyssen. Como é mesmo que Freud falava da civilização?

\section{"O mal-estar na civilização".}

- Qual é o nosso mal-estar hoje? É a nossa impossibilidade de filtrar essa bateria de insumos e de estímulos. Nossos sentidos não estão preparados para isso. Eu vejo essa impossibilidade dentro de todo esse contexto. 
1. A Escola Francesa de Atenas foi fundada em 1846. Cf. http://www.efa.gr/Ecole/ Histoire/acc_ecole hist.htm (acesso em 3/09/2011).

2. A Faculdade de Filosofia, Ciências e Letras da USP funcionou em um conjunto de edifícios da rua Maria Antônia, de 1949 a 1968. Nesse ano, o espaço foi palco de uma batalha que se tornou histórica, entre os alunos da USP e os da Universidade Mackenzie. Com a destruição do prédio, a Faculdade foi transferida para o campus da Cidade Universitária. Cf. http://pt. wikipedia.org/wiki/Centro_Universit\% $\mathrm{C}$ 3\%Alrio_Maria_Ant\%C3\%B4nia_da_Un iversidade de $\bar{S} \% \mathrm{C} 3 \% \mathrm{~A} 30$ Paulo. (acesso em 20/09/2011).

3. Refere-se a Francisco Matarazzo Sobrinho (1893-1977), industrial e mecenas em São Paulo.

4. O Museu de Arte Contemporânea (MAC) da USP foi criado em 1963.

5. O Instituto de Pré-História foi criado em 1952 pelo intelectual Paulo Duarte, que contou com o apoio de Paul Rivet, en- tão diretor do Museu do Homem, em Paris. Inicialmente vinculado à Casa Civil da Presidência da República, foi incorporado à USP em 1962. Coleção Plínio Ayrosa é como ficou conhecido o acervo do Museu de Etnografia, criado em 1935 pelo professor Plínio Ayrosa, regente da cadeira de Etnografia e Línguas Tupi-Guarani da Faculdade de Filosofia, Letras e Ciências Humanas da USP. Cf. http://pt.wikipedia. org/wiki/Museu_de Arqueologia e Etno logia_da_Universidade_de_S\% $\overline{\mathrm{C}} \overline{\mathrm{3}} \mathrm{\overline { \textrm {A } }} \mathrm{A} \mathrm{O}$ Paulo. (acesso em 21/09/2011).

6. Afonso d'Escragnolle Taunay (18761958) foi diretor do Museu Paulista de 1917 a 1945.

7. Condephaat é a sigla do Conselho de Defesa do Patrimônio Histórico, Arqueológico, Artístico e Turístico, órgão ligado à Secretaria de Cultura do Estado de São Paulo.

8. Píer Luigi Cervellati, arquiteto e urbanista foi responsável pela recuperação do centro histórico da cidade de Bolonha. 